talham-se valores e taxas de incremento reais viáveis para o salário mínimo. Também é apresentada uma versão de uma possível Proposta de Emenda Constitucional (PEC) por meio do qual a reforma proposta seria efetuada. Esse seria o caminho para que o país fizesse "A nova escolha de Sofia" , como apropriadamente se denomina o 18을 derradeiro capítulo.

Fica apenas uma breve ressalva quanto a um tema ausente no livro. 0 autor poderia ter incluído um capítulo específico para tratar da pre- vidência dos funcionários públicos, visto que apesar das reformas recentes, os R egimes Próprios de Previdência Social ainda possuem particularidades importantes, que mereceriam uma análise mais acurada. Finalizando, pode-se concluir que esse livro é uma leitura obrigatória para todos aqueles que gostariam de compreender melhor esse importante tema.

Luís Eduardo A fonso

Professor do Departamento de Contabilidade e A tuária da FEA/USP

\title{
Economia da inovação tecnológica
}

Victor Pelaez e Tamás Szmrecsányi (orgs.) São Paulo: H ucitec: O rdem dos Economistas do Brasil, 2006.

A pesar de ter surgido uma ampla literatura econômica acerca das conseqüências da abertura comercial e financeira vivida pela economia brasileira ao longo da década de 1990, ainda se carece do devido entendimento desse cenário concorrencial surgido desde então. R ealmente, se de um lado as empresas brasileiras ficaram submetidas a uma intensa concorrência internacional, de outro, a internacionalização dessas empresas aumentou significativamente 0 acesso a novos mercados e novas fontes de informação. Com isso, 0 conhecimento e a inovação passaram a ser vistos como importantes forças tanto de sobrevivência quanto de aquisição de vantagens competitivas na economia brasileira.

Dequalquer forma, estecenário não éenunca foi exclusividade da economia brasileira, sendo que, com o interesse no estudo da inovação, foi desenvolvida a primeira edição do $M$ anual de O slo em 1992 e, no seu encalço, diversas pesquisas de inovação em vários países. Seguindo essa preocupação, o Instituto Brasileiro de Geografia e Estatística (IBGE) desenvolveria a Pesquisa Industrial de Inovação Tecnológica (Pintec), possibilitando novas linhas de pesquisa então pouco exploradas na literatura econômica brasileira.

É neste contexto que élançado o livro "Economia da inovação tecnológica", com organização de Victor Pelaez e Tamás Szmrecsányi. A obra se divide em três partes. $\mathrm{N}$ a primeira delas, con- tendo cinco capítulos, são apresentados os paradigmas conceituais sob os quais têm se desenvolvido as idéias referentes ao impacto da inovação tecnológica no dinamismo das economias capitalistas. Assim, após trabalhar a conceituação de mercado e concorrência, aborda-se a questão do progresso tecnológico sob as visões marxista, neoclássica, institucionalista e, como não poderia deixar de ser, schumpeteriana.

Já as duas partes seguintes procuram introduzir determinadas questões referentes à inovação nos âmbitos, respectivamente, micro e macroeconômico. Dessa forma, a segunda parte é composta por nove capítulos com a pretensão de abordar alguns dos debates em torno do progresso técnico no âmbito da firma. 0 primeiro deles aborda os diversos entendimentos da relação entre ciência e desenvolvimento tecnológico aplicado à economia. São abordados o modelo linear de inovação - em que a ciência possibilita a aplicação de certos conhecimentos no setor produtivo - , a hipótese de demanda de mercado - em que as necessidades da demanda viabilizam determinadas linhas de pesquisa científica - e, finalmente, o modelo interativo - que sintetiza as duas visões anteriores.

Já o capítulo seguinte analisa a questão da difusão tecnológica, apresentando os diversos modelos de difusão surgidos a partir do trabalho pioneiro de Griliches em 1957, até as contribuições 
dos autores evolucionários. Um capítulo é reservado também para a questão da prospectiva tecnológica, ou "uma política de mobilização de diferentes atores sociais no sentido de estabelecer e atingir metas desejáveis de longo prazo e, ao mesmo tempo, de minimizar os efeitos adversos em nível social, econômico, político, ambiental e cultural". A lém deintroduzir alguns métodos de análise, o autor apresenta as experiências de certos países, quais sejam, Estados Unidos, Japão, Alemanha, Coréia do Sul e o Brasil.

Foco de mais um capítulo é a inserção do papel da inovação na teoria da firma sob diversas visões alternativas, tais como a clássica, a neoclássica e a evolucionária. 0 utros capítulos dessa segunda parte abordam ainda as questões do aprendizado tecnológico. da apropriabilidade dos frutos da inovação, da path dependence, do lockin e da inércia, dos paradigmas e das trajetórias tecnológicas e, finalmente, da economia de redes.

Já a terceira parte do livro compreende quatro capítulos que têm como objetivo contextualizar a inovação tecnológica em importantes questões de ordem macroeconômica. A ssim, o primeiro destes capítulos analisa a influência da tecnologia em dois tópicos extremamente relevantes: a convergência ou divergência da renda per capita en- tre os países ricos e pobres - por meio das teorias cepalina, keynesiana e schumpeteriana - e a relação entre crescimento e distribuição de renda - sob uma perspectiva kaleckiana.

A questão da desigualdade é uma preocupação também do capítulo seguinte, que aborda a influência do progresso técnico sobre a estrutura do emprego, influência esta normalmente associada a um viés favorável ao trabalho qualificado. Finalmente, os dois últimos capítulos abordam, respectivamente, o sistema de inovação e o financiamento de investimentos em inovação.

D evido à sua pretensão eminentemente teórica e introdutória, a obra passa ao largo das recentes evidências empíricas observadas no Brasil e nos países europeus a partir, respectivamente, da Community Innovation Survey e da Pintec. Porém, trata-se sem dúvida de uma importante e relevante contribuição a uma linha de pesquisa que possui um papel fundamental em um país que se mostra incapaz de apresentar significativas taxas de crescimento econômico por mais de dois anos consecutivos.

Alexandre M essa Silva Pesquisador do IPEA 